\title{
Macro Economical Tendencies for Sport Sponsorship Development
}

\author{
Prof. Dr. Pilinkiene Vaida \\ School of Economics and Business of Kaunas University of Technology \\ Email: vaida.pilinkiene@ktu.It
}

\section{Komskiene Diana}

PhD student at School of Economics and Business of Kaunas University of Technology

Email: diana.komskiene@ktu.edu

\section{Doi:10.5901/ajis.2016.v5n3s1p128}

\begin{abstract}
Organization of sports policy priorities and responsibilities are very different in all Member States, with implications on the flow of financial resources to the lowest level, public financing and sport sponsorship. Sports sponsors return on investment generates benefits for the economy as a result of increased activity on sports events, infrastructure development as well as for employment, quality of life or state and city image formation, creating soft power prospects, generating state competitiveness, more revenue from sports tourism, leisure and other sales sectors. All interested parties are funding sport directly and indirectly. For example, companies pay corporate taxes, which generate income to government, which can invest in the sport. However, the government can also define a fiscal framework that is conducive to private companies investing in the sport, such as tax relief. The goal of the article is to reveal the problems of sports funding system on the theoretical basis for sport sponsorship integration. Results indicate, that sports sector in the EU countries limited by the legal framework and the tax burden when the tax ratio is the demand and supply elasticities regulator. On the other hand, a decrease in costs for sporting events or activities of the organization to obtain more funding for sport, modeling macroeconomic legal and tax environment, can provide more opportunities for return on investment for sponsors within the larger media publicity contracts, licensing business expansion, thus generating more sales for sponsors, ensuring higher tax collection in the budget, the growing GDP and social capital development.
\end{abstract}

Keywords: sponsorship, finance, taxes, sports funding, economics.

\section{Introduction}

More and more scientists choose to analyze the economic contribution of the sports industry and other economic effects of the sports industry (Balciunas et al 2014), because the redistribution of public finance systems development and the need of investment growth from private entities becomes a regular challenge for sports sector (Čingienè, 2013). "Money attracts money": this conclusion is supported by the fact that clubs that attract private funding sources, not only their contributions, as well as those who receive public funding: income from government sources, makes a strong incentive to private sources of financing (Eurostrategies, 2011). Although the importance and recognition of sports came only in recent decades, everyone understands that sport affects both as urban and national image as well as economy.

Sponsorship is one of the sports sector' components, without which sport would be existing only fragmenticaly, as sponsorship is one of the largest sources of funds in sport (IEG,; 2012; Jensen \& Cobbs 2014). Sport sponsorship and its activation can be reasonably attributed as a key tool for business results (O'Reilly \& Horning, 2013), and its influence is an important for sport sector and the country's sports and economy.

The total market in the context of the entire still raises questions as to whether the commercial organizations sponsors - shareholders consider and understand the sponsorship as an investment (use of resources, with the intention to increase future production output or income), or is it only a faith for better results in business for management and marketing teams, which is not properly communicated to the fundamental interested parties (Tsiotsou, 2011).

Competition volumes between companies and their profitability is one of the main factors that determine the severity of the tax burden, the implementation of competition for producers to sell their products at the lowest price. The way to reduce the price and demand stimulation is possible. They take the tax burden themself on the expense of profits, but only prosperous businesses have an opportunity in such a way to regulate demand (Abuselidze, 2012). 
In this case, when the tax burden is raised only by prosperous, it is likely a large capital companies, the small and medium-sized businesses overcome with more barriers to integrate into the sports industry, enhance the generation of competitiveness of mutual benefit. For this reason, it can be assumed, it becomes a closed cycle for sports sponsorship phenomenon, declined in demand, on the one hand, due to increasing competition between the sports objects, which are needing the resources to organize activities, but the problems appear due to the decreasing amount of sponsors that can ensure those resources, because of unattractive tax policy of the country.

It is likely that the developed economies (such as the EU countries), with high labor and capital productivity, there are more possibilities to adjust the fees and the assessment of achievements, to identify the conditions that create preconditions for achieving competitive growth and an appropriate level of social environment. The tax burden of communication with the indicators characterizing the long-term social environment and economic growth, identification and communication between disclosure and assessment is a key concern; Research in this area is pretty sketchy (Stankevicius 2014).

Research in the $27 \mathrm{EU}$ countries, and the data indicates that the private small clubs and amateur sporting events funding (through sponsorship, grants or donations) must be promoted both - during economic crisis and when the economic crisis is over (Eurostrategies, 2011).

However, trends in macro economic indicators, such as legal and financial environment in terms of objectives for sponsorship of sports in different economic phases, different sports, participation and spectator sports are not presented or analyzed. The goal is to reveal the problems of sports funding system on the theoretical basis for sport sponsorship integration.

\section{Methods}

Theoretical framework.

Analysis and systemizing of scientific articles and secondary research data.

\section{Analysis}

Amateur sport is largely dependent on local government funding; the financial difficulties faced by the local authorities, may lead to a cyclical shrinking of state subsidies, which may pose a threat to some amateur clubs viability (Eurostrategies, 2011). Therefore, investments of sponsors can contribute to the local and national sports development, as the following core areas on which sponsors usually devote their investments.

According to Schwarz \& Hunter (2008) sports sponsorship investments are classified into 6 categories for:

1. the governing bodies of the sport;

2. sports teams;

3. sportsmen;

4. broadcasting and media;

5. sports facilities (stadiums, arenas);

6. sports events.

Sponsors, while achieving their organizations goals, actually contribute to the quality of life of the city, the country or region, because sports or recreational event or activity, frequently would not be possible for a variety of reasons: the tax burden, the fragmentation / fashion of popularity, the lack of the entrepreneurial and commercial experience of the organizers.

All interested parties are funding sport directly and indirectly. For example, companies pay corporate taxes, which generate income to government, which can invest in the sport. However, the government can also define a fiscal framework that is conducive to private companies investing in the sport, such as tax relief.

Typically, a country that wants to organize large sporting events have to pay the owner the event fees for the rights and bear the costs for the smooth conducting of the event: both organizational and infrastructural (Balciunas et al 2014). Then it becomes especially important to support tax incentives to attract sponsors, because otherwise the fiscal burden lays on the city and the country's population.

Thus, sponsors' money for elite sports, filtered, for example, through the purchase of entry-level of the media rights can fall into the forms of various projects. Meanwhile, sports sponsorship' money flowing horizontally, that is, between the sport disciplines, if infiltrated into the development of infrastructure and development projects, indirectly, affects grassroots sports and sports in general, as well as public welfare development. Changing ways and models of 
sponsorship create new priorities and a greater emphasis on corporate social responsibility, environmental aspects and social projects (Eurostrategies, 2011). It can be said that sponsors provide regeneration for sports entities and objects in various fields of their operations: databases and software updates, training, marketing, skill development, addiction prevention, health programs and so on.

\section{Results and Discussion}

In EU final report for grassroot sports financing (2011), Lithuania was found at a top 3 countries mostly generating revenues from sponsorship, including Cyprus and Slovania. From the 5 most popular sports in 27 th EU researched countries Lithuania was the one, that basketball was the most popular sports discipline, then football, which generates most of the sponsorship investments in Europe.

But the research indicated, that being the most popular discipline in Lithuania, basketball appears to have reduction in sponsorship revenues. Other analyzed research data presented by Baltic Research (2013) indicates that, only about one of five (18\%) of sponsors respondents positively assessed the current legal framework of the sponsorship in Lithuania. Meanwhile, more than two-thirds of respondents (68\%) believe that Lithuania does not yet have a favorable legal environment for sponsorship services. More than one in ten had no opinion on the matter.

Differences in business and the non-for-profit sector's opinion on what should be done to the legal environment becomes more favorable. Non-for-profit sector believe that it is appropriate to give more tax breaks to donors, to improve the legal framework and simplify support procedures.

Business sector primarily emphasizes the need to improve the legal framework, the second identifies the higher tax relief, the third - the support for the simplification of procedures (Baltic Surveys, 2013).

But sports sponsorship phenomenon in Lithuania is treated not as a business sector in achieving goals, the creation of competitive advantages, but only internal motivation without understanding the phenomenon of the economic value of the state economy. Leisure industry, where private investment can solve the problems of the tax burden, is severely restricted by government control in sports sponsorship sector. Baltic studies (2013) indicate that government, is maximizing the control of all areas of life, including charity / sponsorship actions. More than two-thirds of entrepreneurs (67\%) believe that this control of government is totally the main brake for development of sponsorship activities. A similar number of non-for-profit organizations also tend to think so (62\%) (Baltic Surveys, 2013).

It should be noted while modeling attractiveness of legal and tax aspects, that development of viability of the sports sector and its costs usually come of the following financial sources (Eurostrategies, 2011):

- membership fees and other costs of households;

- the economic value of voluntary labor contribution;

- public sector funding at the national, regional and local levels;

- income from fees and charges, lotteries, betting and gambling operators;

- income from sponsors and charities;

- revenues from media rights.

That's why it must be taken into account, that these aspects can be related together and can be combined all of them in the models.

In addition, the changing nature of business categories of sponsors are related to the emergence of new technologies, what makes new suggestions for rethinking of financial and tax models for sponsorship.

As for example, recent trend resulting activation of digital, mobile and on-line media as sponsored sites and social media, such as Twitter and Facebook. The most commonly used activation of sponsorship are examples as follows: advertising and public relations, as well as internal communication, real-time ongoing promotion, hospitality, direct marketing, examples of demonstration during the event, sales promotion and B2B communication. Activation scale often depends on the popularity of sport in a given country (O'Reilly \& Horning 2013).

\section{Conclusions}

Thus, it can be assumed that the sports sponsorship sustainable funding should be balanced in such a way that the sponsors' commercial benefits would be rational ratio equal to the benefit of the society in both vertical and horizontal level.

Secondary data analysis proves that Lithuanian' businessmen approach to sponsorship is associated at low level with the receipt of benefits and creation of added value for the economy of the country, as a common international 
practice. Meanwhile, the state breaks from the sport sector financial support, leaving the sector to deal commercially, but limits the tax liabilities.

Most businesses have the negative perception of the current legal framework of the charity / sponsorship in the Lithuania as well as tax incentives. Excessive state control acts as a brake for sports sponsorship.

The tax burden does not influence only budget revenues, but investments, demand and supply, prices. The tax ratio is clearly identifiable on the demand and supply elasticities. No reducements of the benefits for sponsors, as the legal framework for the case, and tax incentives should support the positive effects on demand and supply of sport sponsorship, because the current tax burden attributable to sporting events, activities and organizers moved on the population, while could be transformed to sponsors. However, legislative and control levers are needed to ensure the balance of tax incentives and tax burdens in the sports sponsorship process to generate economic benefits.

\section{References}

O'Reilly N., Horning, D. L. (2013). Leveraging sponsorship: The activation ratio. Sport Management Review, 16 p. $424-437$.

EUROSTRATEGIES. (2011). Study on the funding of grassroots sports in EU. Final report. Volume 1. http://www.google. It/url?sa=t\&rct=j\&q=\&esrc=s\&source=web\&cd=1\&ved=0ahUKEwiW1OT4juPJAhXEkg8KHTb2B1cQFggdMAA \&url=http\%3A\%2F\%2Fec.europa.eu\%2Finternal_market\%2Ftop_layer\%2Fdocs\%2FFinalReportVol2_en.pdf\&usg=AFQjCNG-NW1KVSc-uMhBvfnOgN8YW3G4g\&sig2=hRiMnlwDzjHnKLie2E_1gA\&bvm=bv.110151844,d.ZWU

Stankevičius E. (2014). Mokesčiu Naštos Poveikio Ekonomikos Konkurencingumui Vertinimas Socialinès Aplinkos Kontekste, Tehnologija.

Tsiotsou R., (2011). A stakeholder approach to international and national sport sponsorship. Journal of Business \& Industrial Marketing, Vol. 26 Iss 8 pp. $557-565$.

Schwarz, C. E., Hunter, D. J. (2008). Advanced theory and practice in sport marketing. United States: Butterworth-Heinemann.

IEG Sponsorship Report. (2012). Economic Uncertainty to Slow Sponsorship Growth in 2012. http://www.sponsorship.com /IEGSR/2012/01/03/Economic - Uncertainty-To-SloSponsorship-Growth-In.aspx

Abuselidze, G. (2012). The Influence Of Tax Burden On Economic Activity And Production Capacity, I'st International Scientific Conference "Problems Of Tax Policy".

Balciunas, M., Jasinskas, E., Koisova, E. (2014), "Economic Contribution of Sports Event: Analysis of Eurobasket 2011 Example", Transformations in Business \& Economics, Vol. 13, No 2 (32), pp.42-55.

Baltijos tyrimai. Lietuvos verslo imoniu, nevyriausybiniu organizaciju apklausa apie filantropiją http://www.3sektorius.It/docs /Filantropija_Verslas2003_2013-01-17_15_26_41.pdf

Čingienè V. (2013). Sportininku rengimo valdymas: socio-ekonominiai aspektai. Sportini darbingumą lemiantys veiksniai (vi). Moksliniu straipsniu rinkinys. Lietuvos sporto universitetas, p. 72-79.

Jensen, J., Cobbs, J. (2014). Analyzing Return-on-Investment in Sponsorship: Modeling BrandExposure, Price, and ROI in Formula One Racing. To appear in Journal of Advertising Research / http://www.academia.edu/4417136/Analyzing_Return-on Investment_in_Sponsorship_Modeling_Brand_Exposure_Price_and_ROI_in_Formula_One_Automobile_Competition 